\title{
Blood stages of Sphaerospora spp. (Myxosporea) in cyprinid fishes
}

\author{
F. Baska, K. Molnár \\ Veterinary Medical Research Institute, Hungarian Academy of Sciences, PO Box 18, H-1581 Budapest, Hungary
}

\begin{abstract}
A total of 398 specimens of 14 cyprinid species were examined for the presence of renal sphaerospores and Sphaerospora blood stages (C blood protozoa). Sphaerospora infection of the kidney was demonstrated in 122 fish of 12 species, and blood stages were found in the blood of 30 fish of 6 species. Blood stages only occurred in fish infected by renal sphaerospores and were primarily demonstrable in fingerlings. Blood forms found in asp Aspius aspius and white bream Blicca bjoerkna differed from those described earlier and contained 16 to 32 secondary cells resembling Sphaerospora swimbladder stages (K protozoa) of common carp. In the blood stages observed in bleak Alburnus alburnus, secondary cells were situated together in an inclusion-like mass within the primary cell, with 1 to 4 nuclei. In bleak and white bream, forms consisting of 1 secondary and 2 tertiary units were also demonstrable. These can be identified as the earliest renal stages of Sphaerospora species. Organisms circulating in the blood so far referred to as ' $\mathrm{C}$ blood protozoa' are probably the early developmental stages of renal sphaerospores.
\end{abstract}

\section{INTRODUCTION}

In the course of studies on the blood of cyprinids infected by renal sphaerospores, Lom et al. (1985) frequently observed parasites resembling the blood protozoa described from the common carp by Csaba (1976). They arrived at the conclusion that these parasites corresponded to early developmental stages of renal Sphaerospora spp. specific for the different fish species. Blood protozoa commonly occurring in the common carp were designated by Molnár (1980) as Csaba-parasites (C protozoa) and by Lom et al. (1983) as unidentified blood organisms (UBO). The above authors and others (Csaba et al. 1984, Ter Höfte et al. 1984, Grupcheva et al. 1985) have attempted to identify these organisms as developmental stages of Sphaerospora renicola. This theory, however, has only recently been confirmed experimentally by Molnár (1988). Kovács-Gayer et al. (1982) and Körting (1982) reported not only on blood stages, but also on the occurrence of myxosporean developmental stages in the swimbladder of Sphaerospora-infected common carp. These stages, which seemed to represent intermediate forms between blood stages and renal stages, were called $\mathrm{K}$ protozoa by many authors - referring to the initials of Kovács-Gayer and Körting. Inoculation of $\mathrm{K}$ stages into infection-free common carp resulted in renal sphaero- sporosis (Molnár 1984, Molnár \& Kovács-Gayer 1986). No such $K$ protozoa have been reported from other cyprinids.

The present paper reports observations proving that in certain cyprinids the $\mathrm{K}$ stages, and within them the so-called triple formations (units composed of a secondary cell and 2 tertiary cells) identifiable with precursors of renal sphaerospore sporogonic stages, are already formed in the blood.

\section{MATERIAL AND METHODS}

Fishes were seined from natural waters of Hungary (Lake Balaton, River Tisza, River Danube, dead channels of the River Körös) and transferred to the laboratory alive. In the majority of fish (total $n=398$ ) only the kidney and swimbladder were examined for Sphaerospora infection; from 150 fish, however, blood smears were also prepared.

Data on the species composition of the fish, rate of Sphaerospora infection, and prevalence of $\mathrm{C}$ blood protozoa are shown in Table 1.

From April to July blood samples were taken randomly via a capillary tube from the caudal vein of the fish. Subsequently the fishes were killed, dissected, and examined for presence of Sphaerospora infection in the 
Table 1. Occurrence of different renal and blood stages of Sphaerospora spp. in cyprinids

\begin{tabular}{|c|c|c|c|c|}
\hline \multirow[t]{2}{*}{ Fishes tested } & \multirow[b]{2}{*}{ Size $(\mathrm{cm})$} & & \multirow{2}{*}{$\begin{array}{c}\text { Sphaerospora } \\
\text { infection in kidney }\end{array}$} & \multirow[b]{2}{*}{ Blood stages ${ }^{d}$} \\
\hline & & $n$ & & \\
\hline Alburnus alburnus (L.) & $3.0-11.0$ & 90 & 44 & $+(11)$ \\
\hline Fingerling & $2.0-2.5$ & 5 & 3 & $+(1)$ \\
\hline Aspius aspius (L.) & $28.0-36.0$ & 2 & 1 & - \\
\hline Fingerling & $2.5-4.0$ & 12 & 11 & $+(4)$ \\
\hline Blicca bjoerknā (L.) & $3.0-15.0$ & 56 & 12 & $+(8)$ \\
\hline Fingerling & 3.0 & 1 & 1 & $+(1)$ \\
\hline Abramis brama (L.) & $7.0-21.0$ & 12 & 5 & - \\
\hline Fingerling & 3.5 & 1 & - & - \\
\hline Abramis ballerus (L.) & 14.0 & 1 & 1 & $+(1)$ \\
\hline Rutilus rutilus (L.) & $3.0-17.0$ & 27 & 5 & - \\
\hline Fingerling & $2.5-3.0$ & 52 & 16 & $+(3)$ \\
\hline Scardinius erythrophthalmus $\{$ L.\} & $4.0-16.0$ & 13 & 1 & $+(1)$ \\
\hline Pelecus cultratus (L.) & $20.0-34.0$ & 3 & 2 & Not uxamined \\
\hline Rhodeus sericeus (Pallas) & $3.0-5.0$ & 20 & 11 & Not examined \\
\hline Phoxinus phoxinus (L.) & $3.0-5.0$ & 20 & - & Not examined \\
\hline Gobio gobio (L.) & $3.0-8.0$ & 13 & 4 & Not examined \\
\hline Carassius auratus gibelio (Bloch) & $4.0-16.0$ & 6 & - & Not examined \\
\hline Ctenopharyngodon idella (Valenciennes) & $5.0-10.0$ & 32 & 2 & Not examined \\
\hline Hypophthalmichthys molitrix (Valenc) & $4.0-16.0$ & 32 & 3 & Not examined \\
\hline
\end{tabular}

kidney. Blood samples were examined first in fresh state under a coverslip, then as Giemsa-stained smears. Infection of the kidney and swimbladder was checked by studying pieces of these organs in squash preparations under a coverslip. In doubtful cases histological sections were also prepared from the organs.

On the blood smears the place of origin, date of collection, species and size of the fish were indicated, and another sign marked whether the fish was infected by renal sphaerospores.

For histological examination the organs were fixed in $10 \%$ buffered formalin or in Bouin's solution, embedded in paraffin, sectioned, and stained with haematoxylin and eosin.

\section{RESULTS}

Sphaerospora spp. parasitizing the kidney were demonstrable from the majority of the fish species tested, i.e. from 12 out of 14 cyprinids. In all cases both spores and developmental stages were found in the renal tubules. The identification of spores extended only to genus level. Neither histological lesions nor $\mathrm{K}$ stages were found in the swimbladder of the dissected fishes.

$C$ blood protozoa were only found in fish infected by renal sphaerospores and were primarily demonstrable in fingerlings a few centimetres in size. In asp Aspius aspius they were found in the blood of almost all sphaerospore-infected fingerlings. In bleak Alburnus alburnus $\mathrm{C}$ blood protozoa were often also found in the blood of older fish. In Table 1 the prevalence of blood stages is marked only with a cross $(+)$. We did not use a more exact marking since blood stages are very difficult to detect if the intensity of infection is low. There were cases when only 1 out of 10 blood smears of the same fish specimen was found to contain $\mathrm{C}$ blood stages.

$\mathrm{C}$ blood stages demonstrated in different fish species exhibited characteristic morphological differences.

\section{Roach Rutilus rutilus, rudd Scardinius erythrophthal- mus, blue bream Abramis ballerus and gudgeon Gobio gobio}

In these fishes blood stages 7 to $15 \mu \mathrm{m}$ in size and resembling in shape those found in common carp Cyprinus carpio occurred (Fig. 1 A to F). Among them there were forms similar to those described by Lom et al. (1985) from roach. These included stages containing a single primary and a single secondary cell and those having 6 to 8 secondary cells in a single primary cell. The more advanced secondary cells contained a tertiary cell each. In some cases 'simple' secondary cells and 'double' ones containing a tertiary cell occurred together in the primary cells (Fig $1 \mathrm{D}$ to $\mathrm{F}$ ). 

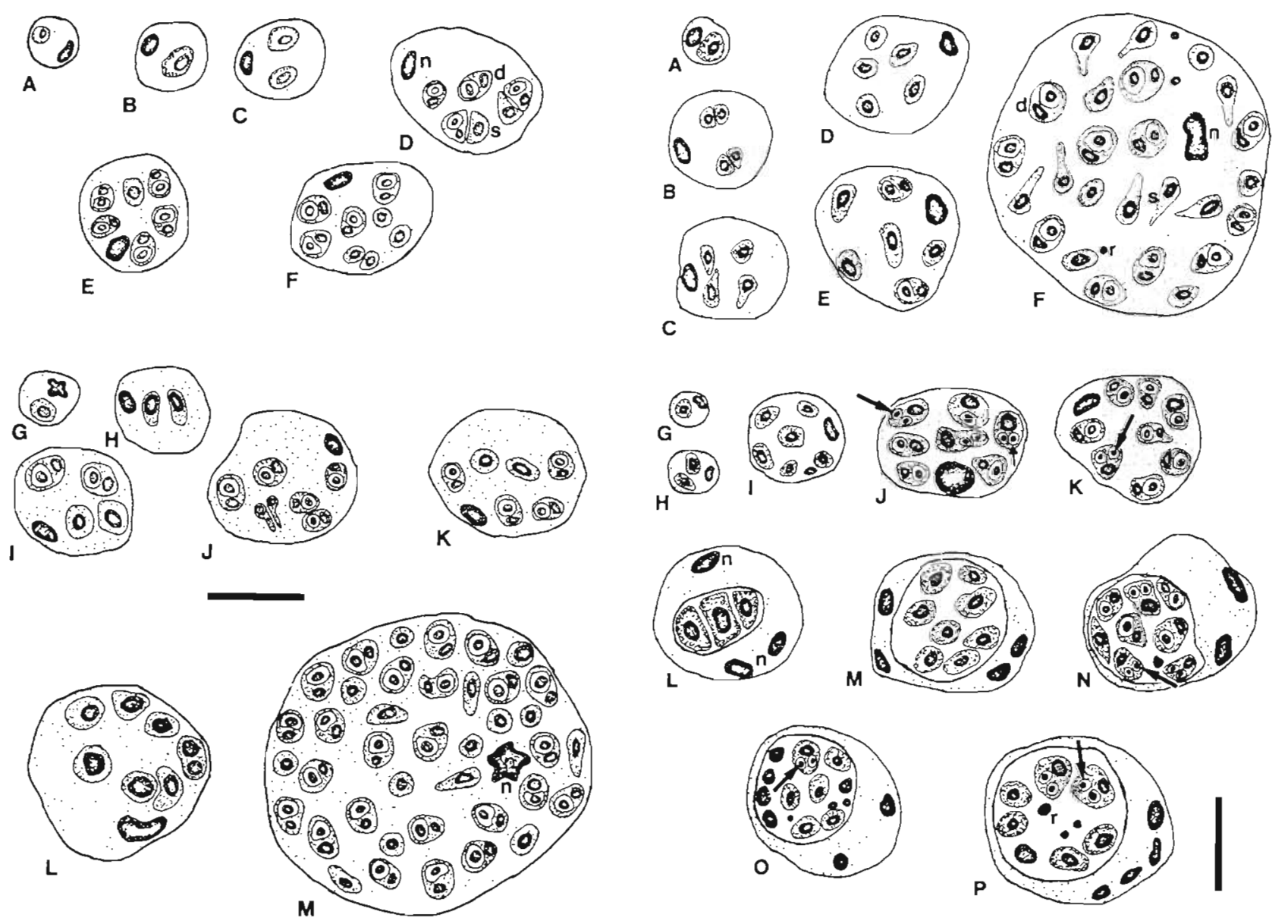

Fig. 1. Sphaerospora developmental stages from the blood of blue bream Abramis ballerus and white bream Blicca bjoerkna. (A to F) Stages resembling blood stages of common carp in the blood of blue bream. Besides the nucleus (n) there are at most 8 secondary cells within a primary cell. The secondary cells are either simple (s), i.e. contain a single nucleus, or double (d), i.e. also contain a tertiary cell. ( $G$ to $\mathrm{L}$ ) Stages resembling blood stages of common carp in the blood of white bream. (M) Stage resembling $\mathrm{K}$ stage of common carp in the blood of white bream. The primary cell contains almost 40 secondary cells $\mathrm{n}$ : nucleus of the primary cell. Bar $=10 \mu \mathrm{m}$

\section{White bream Blicca bjoerkna and asp Aspius aspius}

In these fishes 2 types of $\mathrm{C}$ blood protozoa were commonly discernible. Besides stages comprising a single primary cell and 6 to 8 secondary cells (Figs. $1 \mathrm{G}$ to $L, 2 A$ to $E$, and $3 A, B$ ) there frequently occurred forms 20 to $60 \mu \mathrm{m}$ in size and resembling the $\mathrm{K}$ stages known from the swimbladder of common carp. In the cytoplasm of the enormous primary cell, besides the nucleus of the primary cell there were 16 to 40 secondary cells and, occasionally, a few dark-red staining bodies (compact cell nuclei surrounded by a narrow cytoplasmic margin). Most of the secondary cells contained a tertiary cell each (Figs. $1 \mathrm{M}, 2 \mathrm{~F}$, and $3 \mathrm{C}$ to $\mathrm{E}$ ).
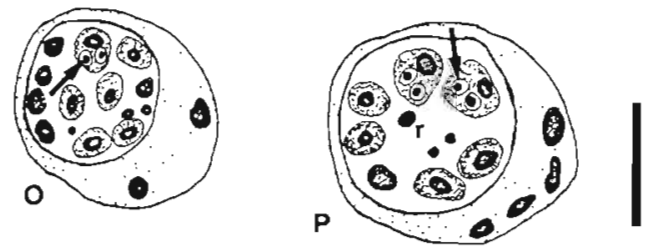

Fig. 2. Sphaerospora developmental stages from the blood of asp Aspius aspius and bleak Alburnus alburnus. (A to E) Stages resembling blood stages of common carp in the blood of asp. (F) Stages resembling $K$ stages of common carp in the blood of asp. Besides the nucleus ( $n$ ), the primary cell contains 11 double (d), 14 simple (s) secondary cells, and 3 so-called residual bodies ( $\mathrm{r}$ ). ( $\mathrm{G}$ to $\mathrm{K}$ ) Sphaerospora blood stages of conventional structure from bleak. The well-developed secondary cells contain 2 tertiary cells (arrow). (L to P) Special Sphaerospora blood stages from bleak. Secondary cells are seen as a distinct vacuole in the cytoplasm of the primary cell. Primary cells may have 2 to 4 nuclei (n). Some secondary cells contain 2 tertiary cells (arrow). Secondary cells resembling the residual body and having little cytoplasm are common ( $\mathrm{r}$ ).

$$
\mathrm{Bar}=10 \mu \mathrm{m}
$$

\section{Bleak Alburnus alburnus}

In this species, in addition to stages resembling those seen in the common carp (Figs. 2G to I and 3F to $H$ ), there were forms that differed from the former in 2 important features. First, the secondary cells occurred as a compact, inclusion-like unit within the primary cells, which were 15 to $30 \mu \mathrm{m}$ in size and had a pale cytoplasm in Giemsa-stained preparations. Second, the primary cells often had 2 to 4 nuclei (Figs. 2L to P and 3I 

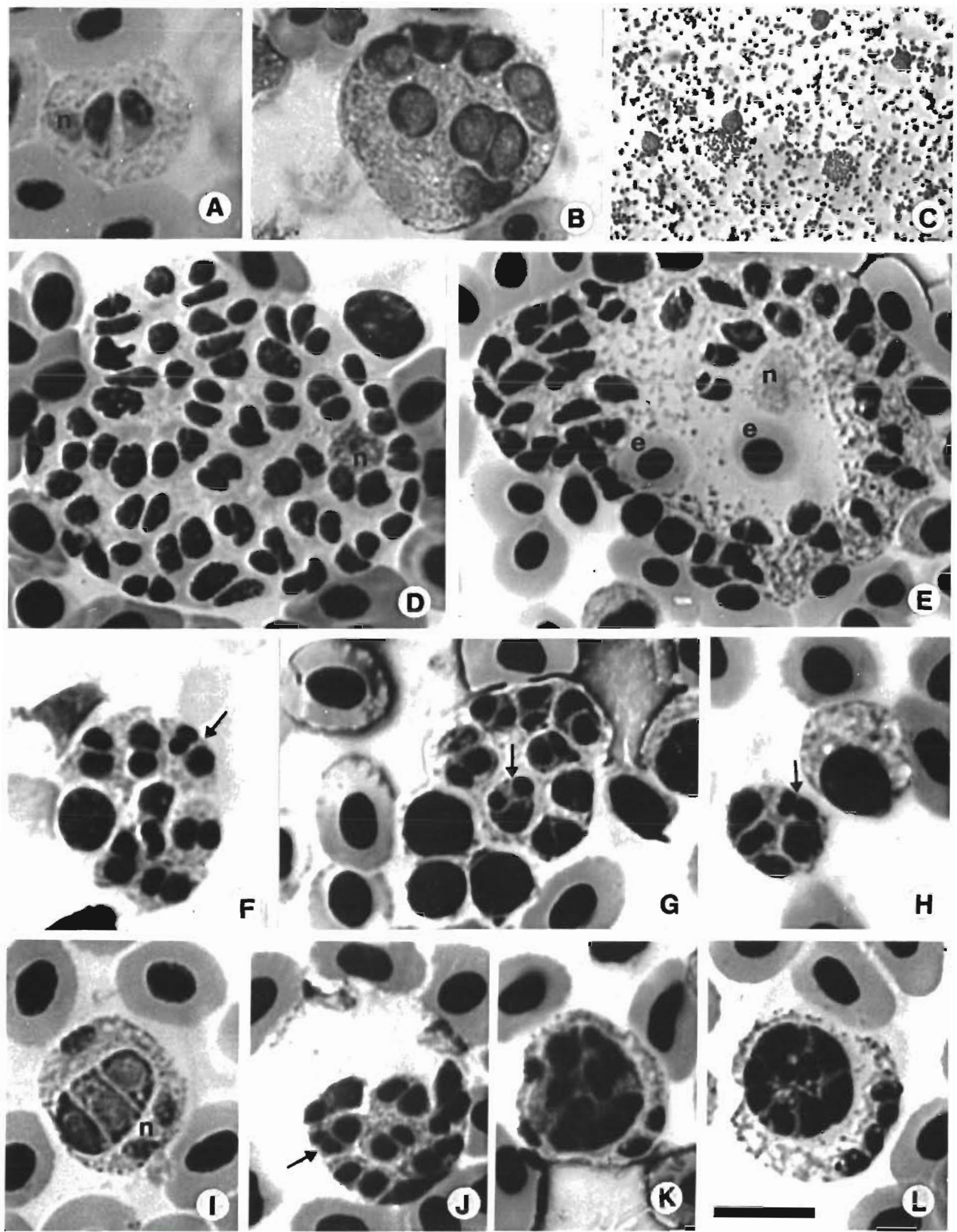

Fig. 3. Sphaerospora blood stages in Giemsa-stained blood preparations of white bream Blicca bjoerkna, asp Aspius aspius, and bleak Alburnus alburnus. (A and B) Young stages containing 2 and 8 secondary cells from white bream. (C and D) Blood stages resembling $\mathrm{K}$ stages of common carp and containing numerous secondary cells, from white bream. n: nucleus of the primary cell, (E) Blood stage containing numerous secondary cells from an asp. n: nucleus of the primary cell; $e=$ erythrocyte. $(F$ to $\mathrm{H})$ Blood stage containing a primary cell nucleus and 6 to 8 secondary celis from bleak. Some secondary cells contain 2 tertiary cells which, together with the secondary cell nucleus, constitute the so-called triple formations (arrow). (I to L) Secondary cells situated like a distinct vacuole in the cytoplasm of a primary cell with 2 to 4 nuclei (n), from the blood of bleak. Arrow: triple formation. Bar in (L) 
to L). In the majority of cases the secondary cells contained a single tertiary cell. In some cases, however, there were 2 tertiary cells within both the inclusion-like secondary cells and the normally located ones (Fig. 2J, $\mathrm{K}, \mathrm{N}$ to $\mathrm{P}$ and $3 \mathrm{~F}, \mathrm{G}, \mathrm{H}, \mathrm{J}$ ). These forms, consisting of a single secondary and 2 tertiary cells, resembled the triple formations developing in the $\mathrm{K}$ stages known from the swimbladder of common carp, and identified by Csaba et al. (1984) as pansporoblasts of Sphaerospora renicola. On one occasion such triple formations were also demonstrable in a blood smear from an asp.

\section{DISCUSSION}

Results indicate that $\mathrm{C}$ blood protozoa are rather common in cyprinids. The coincidence of $\mathrm{C}$ blood protozoan infection and Sphaerospora infestation of the kidney is striking. In common carp numerous investigators (Molnár 1980, Kovács-Gayer et al. 1982, Lom et al. 1983, Csaba et al. 1984, Ter-Höfte et al. 1984) suggested that these blood parasites, together with $\mathrm{K}$ protozoa found in the swimbladder, were developmental stages of myxosporeans, more precisely of sphaerospores. This hypothesis was supported by investigations by Lom et al. (1985) who also demonstrated the presence of blood stages in Sphaerospora-infected gudgeon, roach and tench. The present studies have furnished new evidence that the appearance of blood stages in sphaerospore-infected cyprinids can be considered normal. Together with the experimental data of Molnár (1984, 1988), results indicate that $\mathrm{C}$ and $\mathrm{K}$ stages, whose taxonomic position has long been a subject of controversy, are developmental stages of Sphaerospora spp

The development of sphaerospores (and possibly also that of closely related species, e.g. the PKX organism, the causative agent of proliferative kidney disease in salmonids: Kent \& Hedrick 1986) obviously has several phases and takes place in more than one organ. This development always includes a blood stage. It is recommended, therefore, that parasites so far referred to as ' $\mathrm{C}$ blood protozoa' (or 'UBO') and ' $\mathrm{K}$ protozoa' should in future be called Sphaerospora blood stages (C stage) and Sphaerospora swimbladder stage (K stage).

Results also show that blood stages occurring in different fish species may vary considerably in morphology and are characteristic of the given fish species. This morphological diversity arises from 4 properties.

(1) Sphaerospora blood stages characteristic of common carp contain 8 secondary and 8 tertiary cells in a primary cell, while in asp and white bream stages containing 16 to 40 secondary and tertiary cells are also common.
(2) In the cytoplasm of the primary cell the secondary cells are sometimes segregated like inclusions.

(3) Primary cells may have as many as 2 to 4 nuclei.

(4) Some secondary cells contain 2 tertiary cells.

The morphological diversity of Sphaerospora stages in the blood of common carp has been documented abundantly by Csaba (1976), Lom et al. (1983) and TerHöfte et al. (1984). However, none of these research groups could find in the blood of common carp primary cells containing more than 8 secondary cells. Lom et al. (1985) were the first to suggest that primary cells might contain more than 8 secondary cells: they found 6 double and 7 single secondary cells in the blood stage found in Gobio gobio. On one occasion the same authors observed in common carp a blood stage containing 15 secondary cells. They state, however, that stages containing numerous secondary cells typically occur in organs other the blood (e.g. in the swimbladder and eye). In the present studies, in white bream and asp Sphaerospora blood stages containing numerous secondary cells were very common, and these developmental stages were morphologically identical to $\mathrm{K}$ stages known from the swimbladder of common carp. In these species development in the blood seems to be continuous and is not interrupted at a certain stage; rather, the swimbladder stage is omitted and the cycle is completed. The multinucleated forms characteristic of $\mathrm{K}$ stages develop in the blood itself and near the end of development triple formations appear. These latter can be regarded as precursors of the earliest sporogonic Sphaerospora stages observed in the renal tubules, which are pansporoblasts with 2 sporoblasts.

Another important feature of Sphaerospora blood stages described from cyprinids is that the secondary cells constitute a single closed unit surrounded by the cytoplasm of the primary cell. This peculiarity in location has been reported by Csaba et al. (1984) and TerHöfte et al. (1984). Csaba et al. (1984) demonstrated such forms in $\mathrm{K}$ stages of common carp while Ter-Höfte et al. (1984) found them in blood stages. In these blood stages secondary cells were located in the cytoplasm of the primary cell as if in a vacuole. These secondary cells, seen as distinctly segregated units in the pale cytoplasm of the primary cell, were particularly common in the blood of bleak.

Another striking feature of the stages found in bleak was that the primary cells occasionally had 2, 3 or even 4 nuclei. Myxosporeans are known to have, in addition to the generative cells, numerous vegetative nuclei of trophic function within the plasmodium. In the present case the supernumerary nuclei of the primary cell can be considered such vegetative nuclei. These nuclei were only found in bleak. Lom et al. (1985) published a photograph of a blood stage which they regarded as a primary cell with 2 secondary cells and phagocytised 
blood cell. However, we cannot exclude the possibility that this blood stage represented a multinucleated primary cell with inclusion-like secondary cells.

The Sphaerospora nature of the blood stages is, however, best proved by the triple formations that were detected in bleak and asp on several occasions. These triple formations completely corresponded to those found in $\mathrm{K}$ stages of common carp and these latter, in turn, are identical to the earliest Sphaerospora developmental stages present in the renal tubules, as has been proved experimentally by Molnár \& KovácsGayer (1986).

In the cyprinids examined by us, especially in bleak, asp and white bream, the Sphaerospora blood stages had morphological characteristics mostly typical for the given fish species. These morphological features can be considered species characters and seem to support the suggestion by Lom et al. (1985) that sphaerospores inhabiting the renal tubules of taxonomically closely related cyprinids, and hardly distinguishable by spore morphology, actually represent separate species.

\section{LITERATURE CITED}

Csaba, G. (1976). An unidentifiable extracellular sporozoan parasite from the blood of the carp. Parasit. Hung. 9: 21-24

Csaba, G., Kovács-Gayer, É., Békési, L, Bucsek, M., Szakolczai, J., Molnár, K. (1984). Studies into the possible protozoan aetiology of swimbladder inflammation in carp fry. J. Fish Dis. 7. 39-56

Grupcheva, G., Dykova, I., Lom, J. (1985). Seasonal fluctuation in the prevalence of Sphaerosopra renicola and myxosporean blood-stream stages in carp fingerlings in Bulgaria. Fol. Paras. (Praha) 32: 193-203
Kent, M. L., Hedrick, R. P. (1986). Development of the PKX myxosporean in rainbow trout Salmo gairdneri. Dis. Aquat. Org 1: 169-182

Kovács-Gayer, É., Csaba, G., Békési, L., Bucsek, M., Szakolczai, J., Molnar, K. (1982). Studies on the protozoan etiology of Swimbladder Inflammation in common carp fry. Bull. Eur. Ass. Fish Pathol. 2: 22-24

Körting, W. (1982). Protozoan parasites associated with swimbladder inflammation (SBI) in young carp. Bull. Eur. Ass. Fish Pathol 2: 25-28

Lom, J., Dykova, I., Pavlásková, M. (1983). 'Unidentified' mobile protozoans from the blood of carp and some unsolved problems of myxosporean life cycles. J. Protozool. 30: 497-508

Lom, J., Pavlásková, M., Dykova, I. (1985). Notes on kidneyinfecting species of the genus Sphaerospora Thélohan (Myxosporea), including a new species $S$. gobionis sp. nov., and on myxosporean life cycle stages in the blood of some freshwater fish. J. Fish Dis. 8: 221-232

Molnár, K. (1980). 'Sphaerosporosis', a new kidney disease of the common carp. In: Ahne, W. (ed.) Fish diseases Springer-Verlag, Berlin, p. 157-164

Molnár, K. (1984). Experimental evidence that protozoa causing swimbladder inflammation in common carp (Cyprinus carpio) are stages of Sphaerospora renicola. Bull Eur. Ass Fish Pathol. 4: 14-15

Molnár, K. (1988). Evidence that C-blood protozod of the common carp are stages of Sphaerospora renicola Dyková et Lom, 1982. Bull. Eur. Ass. Fish Pathol. 8: 3-4

Molnár, K., Kovács-Gayer, E. (1986). Experimental induction of Sphaerospora renicola (Myxosporea) infection in common carp (Cyprinus carpio) by transmission of SB-protozoans. J. appl. Ichthyol 2: 86-94

Ter-Höfte, B. B., Körting, W., Lehmann, J. (1984). 'C und KProtozoen', Endoparasiten unsicherer systematischer Zuordnung bei jungen Karpfen (Cyprinus carpio L.). Derzeitiger Wissensstand und bildliche Dokumentation. Fisch und Umwelt 13: 89-99. G. Fischer Verlag, Stuttgart, New York 